Original Research

Agrinula : Jurnal Agroteknologi dan Perkebunan 2020 vol. 3 (1): $28-36$

website : https://journal.utnd.ac.id/index.php/agri

E-ISSN : 2655-7673

DOI : https://doi.org/10.36490/agri.v3i1.83

\title{
EKSPLORASI MAKROFAUNA TANAH DI TANAMAN KAKAO PADA MUSIM KEMARAU
}

\section{SOIL MACROFAUNA EXPLORATION IN COCOA PLANTS DURING THE DRY SEASON}

\section{Octanina Sari Sijabat ${ }^{1 *}$, Yunida Berliana ${ }^{2}$, \& Ahmad Nadhira ${ }^{2}$}

${ }^{1}$ Program Studi Budidaya Perkebunan, Fakultas Pertanian dan Peternakan, Universitas Tjut Nyak Dhien, Medan 20123, Sumatera Utara, Indonesia

${ }^{2}$ Program Studi Agroteknologi, Fakultas Pertanian dan Peternakan, Universitas Tjut Nyak Dhien, Medan 20123, Sumatera Utara, Indonesia

*Koresponding author: octanina366@gmail.com

\begin{tabular}{|c|c|}
\hline Informasi Artikel & ABSTRAK \\
\hline \multirow[t]{3}{*}{$\begin{array}{l}\text { Disubmit: } \\
12 \text { Maret } 2020 \\
\text { Direvisi: } \\
\text { 12 April } 2020 \\
\text { Diterima: } \\
\text { 13 April } 2020 \\
\text { Dipublikasi: } \\
13 \text { April } 2020\end{array}$} & $\begin{array}{l}\text { - Pendahuluan: Tujuan penelitian ini untuk } \\
\text { mengidentifikasi jenis makrofauna tanah yang ada pada } \\
\text { tanaman kakao yang menghasilkan dan tanaman kakao } \\
\text { yang belum menghasilkan. } \\
\text { Metode Penelitian: Penelitian ini dilaksanakan di kebun } \\
\text { kakao rakyat, Kabupaten Langkat, dan dilanjutkan } \\
\text { identifikasi serangga di Laboratorium Hama Tanaman, } \\
\text { Fakultas Pertanian, Universitas Sumatera Utara, Medan } \\
\text { dari bulan April sampai Mei 2019. Penelitian ini } \\
\text { menggunakan metode deksriptif kuantitatif. } \\
\text { Hasil Penelitian: terdapat beberapa ordo Hymenoptera, } \\
\text { Orthoptera, Coleoptera, Oligochaeta, dan Araneae } \\
\text { dengan jumlah makrofauna yang berbeda. } \\
\text { Kata Kunci: identifikasi; keanekaragaman; serangga tanah }\end{array}$ \\
\hline & ABSTRACT \\
\hline & $\begin{array}{l}\text { - Introduction: The purpose of this research was aimed to } \\
\text { identify the types of soil macrofauna in mature and } \\
\text { immature of cocoa. } \\
\text { - Materials and Methods: The research has been }\end{array}$ \\
\hline
\end{tabular}




\begin{tabular}{|l|l|}
\hline conducted at cocoa of smallholder, Langkat District and \\
continued with insect identification at the Laboratory of \\
Plant Pest, Faculty of Agriculture, Universitas Sumatera \\
Utara, Medan from April until May 2019. The research \\
was used the quantitative descriptive methods. \\
- Results: found in several orders of Hymenoptera, \\
Orthoptera, Coleoptera, Oligochaeta, and Araneae with \\
different numbers of macrofauna. \\
Keywords: diversity; identification; soil insects
\end{tabular}

\section{PENDAHULUAN}

Tanah terdiri dari sifat fisik, kimia dan biologi, sifat ini mempengaruhi kondisi tanah. Biologi tanah mempunyai peran penting dalam meningkatkan produktivitas lahan karena pengaruh pengelolaan lahan yang buruk dapat mempengaruhi keberadaan mikroorganisme dan juga jumlah makrofauna yang berperan sebagai dekomposer bahan organik serta pengaruh umur tanaman. Sehingga penting diketahui jenis makrofauna yang berperan untuk menentukan atau sebagai indikator kesuburan tanah pada areal tanaman. Siregar et al., (2019) menyatakan adanya perbedaan keanekaragaman makrofauna tanah pada tanaman menghasilkan lebih tinggi apabila dibandingkan dengan tanaman belum menghasilkan.

Keberadaan serangga didalam tanah yang berada pada suatu tempat dipengaruhi oleh faktor lingkungan, baik itu faktor biotik maupun faktor abiotik. Faktor abiotik meliputi tanah, air, suhu, cahaya, dan atmosfir. Sedangkan faktor biotik meliputi tumbuhan dan hewan yang ada di lingkungan tersebut. Szujecki, (1987); Rahmawaty, (2000) menyebutkan adanya faktor-faktor yang dapat mempengaruhi kehadiran serangga tanah di hutan, meliputi struktur yang ada pada tanah berpengaruh terhadap suatu gerakan dan penetrasi, kondisi kelembaban tanah dan kandungan hara yang dapat berpengaruh terhadap perkembangan dalam daur hidup, suhu tanah yang akan mempengaruhi peletakan telur, cahaya dan tata udara sehingga mempengaruhi aktivitas serangga tanah.

Jenis insekta yang berperan sebagai dekomposer yang terdapat dilingkungan hutan heterogen sejumlah 194 ispesies dan hutan homogen sejumlah 40 spesies. Kondisi ini dapat diartikan bahwa keanekaragaman lebih tinggi ditemukan pada hutan heterogen bila dibandingkan tingkat keanekaragaman hutan homogeny yang lebih rendah (Sari, 2015).

Dengan demikian diperlukan eksplorasi serangga pada tanaman kakao untuk mendapatkan kerapatan dan indeks keanekaragaman serangga pada musim kemarau. Tujuan penelitian ini untuk mengidentifikasi jenis makrofauna tanah yang ada pada tanaman kakao yang menghasilkan dan tanaman kakao yang belum menghasilkan.

\section{METODE PENELITIAN}

Penelitian ini dilaksanakan pada April sampai Mei 2019. Eksplorasi makrofauna dilakukan dikebun petani rakyat di Kabupaten Langkat, dan dilanjutkan identifikasi 
serangga di Laboratorium Hama Tanaman, Fakultas Pertanian, Universitas Sumatera Utara, Medan.

Adapun lahan pertanaman yang digunakan adalah tanaman kakao yang menghasilkan (TM) umur 5 tahun dengan luas lahan masing-masing $400 \mathrm{~m}^{2}$. Alat dan bahan yang digunakan dalam penelitian ini adalah Soil Sampler ukuran 25 x 25 x 30 cm, cangkul, gunting, meteran, botol, kaca pembesar, pinset, alkohol 70\%, mikroskop, kamera. pisau bedah, tatakan stainless, cawan petri, beaker glass, lampu bunsen, tabung Erlenmeyer. Penelitian menggunakan metode deskriptif kuantitatif. Metode pemantauan keberadaan serangga langsung dilakukan dilahan pertanaman kakao rakyat seluas 0,5 ha kemudian dilakukan eksplorasi.

Rumus perhitungan kerapatan mutlak, dan kerapatan relatif yang digunakan pada penelitian ini mengacu menurut Purba, (2014):

Kerapatan Mutlak $(\mathrm{KM})=$ Jumlah serangga tertentu yang terdapat pada habitat

Kerapatan Relatif $(\mathrm{KR})=\frac{\text { Kerapatan Spesies tertentu }}{\text { Kerapatan mutlak Semua Spesies }} \times 100 \%$

Rumus indeks keanekaragaman serangga yang digunakan pada penelitian ini mengacu perhitungan indeks Shannon-Wiener (Shannon dan Weaver, 1949):

Indeks keanekaragaman $\left(\mathrm{H}^{\prime}\right)=-\sum_{i=1}^{S}\left[\left(\frac{\mathrm{ni}}{\mathrm{N}}\right) \ln \left(\frac{\mathrm{ni}}{\mathrm{N}}\right)\right]$

Keterangan:

$$
\begin{aligned}
& \mathrm{H}^{\prime}=\text { indeks keanekaragaman Shannon-Wiener } \\
& \mathrm{S}=\text { jumlah spesies } \\
& \mathrm{ni} \quad=\text { jumlah individu spesies-i } \\
& \mathrm{N}=\text { total jumlah individu semua spesies } \\
& \mathrm{ln}=\text { logaritma natural }
\end{aligned}
$$

\section{HASIL DAN PEMBAHASAN}

\section{Klasifikasi Serangga Tanah}

Jenis serangga yang ditemukan dilokasi penelirian pada areal TM ditemukan sebanyak 6 ordo dengan 7 famili, yaitu Hymenoptera pada famili Formicidae, Orthoptera pada famili Gryllidae, Arachinida pada famili Lycosidae, dan Coleoptera pada famili Scarabaeidae (Tabel 1).

Berdasarkan Tabel 1, diperoleh serangga dengan ordo Hymenoptera dan Diptera lebih dominan dibandingkan ordo lainnya pada kondisi tanaman kakao menghasilkan. Pada kondisi tanaman kakao belum menghasilkan didomnasi serangga berordo Hymenoptera.

\section{Indeks Keanekaragaman Serangga Tanah}

Hasil perhitungan indeks keanekaragaman serangga tanah pada areal TM dan TBM perkebunan kakao rakyat dapat dilihat pada Tabel 2. Berdasarkan nilai indeks keanekaragaman (H') diketahui bahwa indeks keanekaragaman pada TM tergolong sedang, sedangkan indeks keanekaragaman pada TBM tergolong rendah. 
Tabel 1. Klasifikasi serangga tanah yang ditemukan pada areal perkebunan kakao rakyat.

\begin{tabular}{lllllcc}
\hline \multirow{2}{*}{ No } & \multirow{2}{*}{ Ordo } & \multirow{2}{*}{ Spesies } & Nama Indonesia & \multicolumn{2}{c}{ Lokasi } & \multirow{2}{*}{ Jumlah } \\
\cline { 4 - 6 } & & & & TM & TBM & \\
\hline 1 & Hymenoptera & Dolichoderus thoracicus & Semut hitam & 10 & 2 & 12 \\
& & Formica pallidefulva & Semut api & 5 & 10 & 15 \\
& & Anoplolepis gracilipes & Semut kuning & 11 & 4 & 15 \\
\hline 2 & Coleoptera & Megasoma vogti & Kumbang tanduk & - & 1 & 1 \\
\hline 3 & Orthoptera & Gryllus bimaculatus & Jangkrik & 5 & 2 & 7 \\
& & Blattela spp. & Kecoa & 3 & - & 3 \\
\hline 4 & Arachinida & Pardosa pseudoannulata & Laba-laba & 1 & 3 & 4 \\
\hline 5 & Diptera & Bactrocera dorsalis & Lalat buah & 15 & - & 15 \\
\hline 6 & Oligochaeta & Pontoscolex $s p$ & Cacing & 2 & 5 & 7 \\
\hline
\end{tabular}

Tabel 2. Indeks keanekaragaman serangga tanah ( $\left.\mathrm{H}^{\prime}\right)$

\begin{tabular}{lcccccc}
\hline \multirow{2}{*}{ Spesies } & \multicolumn{2}{c}{ Lokasi } & \multicolumn{2}{c}{ Pi } & \multicolumn{2}{c}{$\mathrm{H}^{\prime}=-\sum \mathrm{Pi} \ln (\mathrm{Pi})$} \\
\cline { 2 - 7 } & TM & TBM & TM & TBM & TM & TBM \\
\hline 1. Dolichoderus thoracicus & 10 & 2 & 0,19 & 0,07 & $-0,31$ & $-0,18$ \\
2. Formica pallidefulva & 5 & 10 & 0,09 & 0,37 & $-0,21$ & $-0,36$ \\
3. Anoplolepis gracilipes & 11 & 4 & 0,21 & 0,14 & $-0,32$ & $-0,27$ \\
4. Megasoma vogti & 0 & 1 & 0,00 & 0,03 & - & $-0,10$ \\
5. Gryllus bimaculatus & 5 & 2 & 0,09 & 0,07 & $-0,21$ & $-0,18$ \\
6. Blattela spp. & 3 & - & 0,05 & 0,00 & $-0,14$ & - \\
7. Pardosa pseudoannulata & 1 & 3 & 0,01 & 0,11 & $-0,04$ & $-0,24$ \\
8. Bactrocera dorsalis & 15 & - & 0,28 & 0,00 & $-0,35$ & - \\
9. Pontoscolex sp & 2 & 5 & 0,03 & 0,18 & $-0,10$ & 0,30 \\
\hline Jumlah & 52 & 27 & & & 1,68 & 1,63 \\
\hline
\end{tabular}

Hal ini disebabkan jenis tanaman yang diusahakan secara monokultur dalam areal yang sangat luas serta penggunaan pestisida sebagai tindakan pengendalian yang menyebabkan terjadinya modifikasi pada keberadaan habitat serangga. Hal ini disebabkan jenis tanaman yang diusahakan secara monokultur dalam areal yang sangat luas serta penggunaan pestisida mempengaruhi keberadaan makrofauna. Menurut Siregar et al., (2019) menyatakan bahwa tanama nmenghasilkan keanekaragamannya lebih tinggi apabila dibandingkan tanaman belum menghasilkan. Haneda et al., (2013) menyatakan bahwa keanekaragaman serangga dipengaruhi oleh faktor kualitas dan kuantitas makanan, antara lain banyaknya tanaman inang yang cocok, kerapatan tanaman inang, umur tanaman inang dan komposisi tegakan. Odum, (1998) menyatakan bahwa keanekaragaman jenis ditunjukkan oleh banyaknya jenis organisme yang membentuk komunitas di kawasan tertentu. Suatu komunitas dikatakan memiliki keanekaragaman yang tinggi apabila suatu komunitas itu ditempati oleh banyak spesies begitu juga sebaliknya. Borror et al., (1992) menyatakan bahwa suatu komunitas dikatakan mempunyai keanekaragaman spesies yang tinggi apabila pada komunitas itu ditempati oleh sejumlah spesies insekta dengan kelimpahan sama atau hampir sama. 


\section{Nilai Kerapatan Mutlak dan Kerapatan Relatif}

Penangkapan setelah dikumpulkan, dikelompokkan dan diidentifikasi kemudian dianalisis dengan menghitung kerapatan mutlak dan kerapatan relatif. Menurut Michael, (1995) kerapatan mutlak merupakan jumlah insekta yang didapat pada habitat dan dapat dinyatakan secara mutlak. Hasil perhitungan nilai kerapatan mutlak dan kerapatan relatif terdapat pada Tabel 3.

Tabel 3. Nilai kerapatan mutlak dan kerapatan relatif serangga tanah pada areal TM dan TBM perkebunan kakao rakyat.

\begin{tabular}{cllcccc}
\hline \multirow{2}{*}{ No } & \multirow{2}{*}{ Nama Famili } & \multirow{2}{*}{ Spesies } & \multicolumn{2}{c}{ TM } & \multicolumn{2}{c}{ TBM } \\
\cline { 3 - 6 } & & & KM & KR $(\%)$ & KM & KR(\%) \\
\hline \multirow{2}{*}{ Formicidae } & Dolichoderus thoracicus & 10 & 19,23 & 2 & 7.41 \\
& & Formica pallidefulva & 5 & 9,62 & 10 & 37,04 \\
& & Anoplolepis gracilipes & 11 & 21,15 & 4 & 14,81 \\
\hline 2 & Scarabaeidae & Megasoma vogti & - & 0,00 & 1 & 3,71 \\
\hline 3 & Gryllidae & Gryllus bimaculatus & 5 & 9,61 & 2 & 7,40 \\
& Blattidae & Blattela spp. & 3 & 5,77 & - & 0,00 \\
\hline 4 & Araneae & Pardosa pseudoannulata & 1 & 1,93 & 3 & 11,12 \\
\hline 5 & Drosophilidae & Bactrocera dorsalis & 15 & 28,84 & - & 0,00 \\
\hline 6 & Oligochaeta & Pontoscolex sp & 2 & 3,85 & 5 & 18,51 \\
\hline & & Total & 52 & 100,00 & 27 & 100,00 \\
\hline
\end{tabular}

Keterangan : $\mathrm{KM}=$ kerapatan mutlak; $\mathrm{KR}=$ kerapatan relatif.

Berdasarkan Tabel 3, diketahui bahwa nilai kerapatan mutlak dan kerapatan relatif tertinggi pada areal TM kakao terdapat pada famili Drosophilidae yang didominasi spesies Bactrocera dorsalis dengan nilai KM sebesar 15 dan KR sebesar 28,84\%, sedangkan nilai terendah terdapat pada family Araneae yakni spesies laba-laba dengan nilai KM sebesar 1 dan KR sebesar 1,93\%. Pada pengamatan areal pertanaman kakao TBM diketahui nilai kerapatan mutlak dan kerapatan relatif tertinggi pada lahan kakao TBM terdapat pada famili Formicidae yang didominasi spesies Bactrocera dorsalis dengan nilai KM sebesar 10 dan KR sebesar 37,04\%, sedangkan nilai terendah terdapat pada famili Scarabidae yakni spesies Megasoma vogti dengan nilai KM 1 dan KR sebesar 3,71\%.

Dari hasil analisa data yang telah dilakukan didapat nilai kepadatan dan kepadatan relatif serangga tanah yang bervariasi pada pertanaman kakao menghasilkan dan belum menghasilkan. Jumlah serangga tanah yang paling tinggi didapatkan pada tanaman menghasilkan adalah Dolichoderus thoracicus dengan nilai KR 28,84\% dan tanaman belum menghasilkan adalah spesies Formica pallidefulva dengan nilai 37,04\%. Menurut Suin, (2012) apabila terdapat kerapatan sejenis hewan disuatu daerah sangat berlimpah, hal ini mengindikasikan bahwa kondisi faktor lingkungan biotik (produsen, konsumen, dan dekomposer) dan abiotik (fisika-kimia tanah, seperti suhu, kelembaban, pH, kandungan organik, dan lain sebagainya) pada daerah tersebut sangat mendukung kelangsungan kehidupan hewan tersebut.dan sebaliknya. 


\section{Jenis dan Deskripsi Serangga}

Identifikasi jenis dan deskripsi serangga yang ditemukan dilapangan menggunakan Gullan \& Cranston, (2010) sebagai berikut:

\section{Famili Formacidae.}

Kelompok famili formicidae ini terdiri atas keluarga semut-semut yang banyak ditemukan di permukaan tanah. Banyaknya individu yang diperoleh disebabkan karena jenis ini merupakan jenis yang hidup secara berkoloni. Dengan hidup secara berkoloni peluang individu dalam kelompok untuk mempertahankan hidup semakin meningkat.

Berdasarkan hasil penelitian, diperoleh sebanyak 42 ekor serangga dari famili Formacidae, masing-masing 26 dan 16 ekor pada areal pertanaman kakao TM dan TBM. Spesies yang ditemukan adalah Dolichoderus thoracicus (Semut hitam), Formica pallidefulva (Semut api), dan Anoplolepis gracilipes (Semut kuning). Serangga pada famili ini memiliki ciri-ciri panjang tubuh $1 \mathrm{~cm}$, warna hitam, memiliki 1 pasang antena, bentuk caput oval, mata oval dan terletak pada posisi kesamping dengan tipe mulut menggigit, tungkai 3 pasang, tidak memiliki sayap, bentuk tungkai pedicel (metasoma), sungut menyiku dan pada ruas pertama sangat panjang, ruas metasoma kedua mengandung satu punuk (bungkul) dan abdomen oval. serangga ini berperan sebagai pemangsa yang memakan serangga kecil dan juga bunga yang memiliki nectar.

Ditemukanya famili formacidae disebabkan faktor lingkungan yang sesuai dengan kehidupan serangga ini.Faktor lingkungan tersebut bisa jadi faktor biotik dan abiotiknya. Faktor biotik bisa berupa ketersediaannya jumlah makanan yang ada pada lahan perkebunan dan kurangnya musuh alami dari serangga tersebut. Formica pallidefulva telah memenuhi hampir seluruh bagian bumi. Hanya di beberapa daerah seperti di Islandia, Greenland dan Hawai, serangga tidak memenuhi daerah tesebut. Semut

Dolichoderus thoracicus biasanya hadir dari sarangnya di saat pagi dan sore hari ketika suhu tidak terlalu panas. Namun, pada siang hari ketika suhu udara mulai panas, semut mulai bersembunyi ditempat-tempat yang terlindungi dari cahaya sinar matahari secara langsung yang dapat masuk ke dalam sarang, di balik daun-daun, di tanah, dan tempat lainnya. Formica pallidefulva mempunyai indera lingkungan yang hampir sempurna untuk mendapatkan makanan dan untuk kembali ke sarangnya dengan meninggalkan zat feromon pada jalur-jalur yang mereka lalui.

\section{Famili Scarabaeidae.}

Serangga pada famili ini yang ditemukan dilokasi pengamatan adalah Megasoma vogti (Kumbang tanduk). Megasoma vogti memiliki ciri-ciri bertubuh $1,51 \mathrm{~cm}$, memiliki warna hitam, terdiri dari 3 pasang kaki dibagian thoraks, dan pada bagian tubuhnya terdapat bulu-bulu. Tipe mulut penggigit. Larva ini dikenal dengan nama lundi, bertubuh silinder dengan bentuk melengkung atau menyerupai huruf C. Megasoma vogti ini juga banyak digunakan sebagai bioindikator stabilnya ekosistem karena tersebar luas diberbagai ekosistem, spesiesnya beragam, muda 
dicuplik memiliki peran penting secara ekologis. Megasoma vogti berperan dalam penguraian kotoran hewan sehingga terlibat dalam siklus hara dan penyebaran biji pada tumbuh-tumbuhan yang terbawa melalui kotoran. Dengan demikian, Megasoma vogti merupakan bagian yang penting dalam ekosistem untuk mempertahankan keseimbangan alam dan rantai makanan.

\section{Famili Gryllidae}

Serangga dari famili ini yang ditemukan adalah Gryllus bimaculatus (Jangkrik). Jangkrik bisa ditemukan di celah batu-batuan, kayu-kayu yang mulai lapuk, tebing sungai dan di semak belukar serta dapat hidup pada celah lubang yang ada di tanah. Jangkrik bias dilihat di hampir seluruh wilayah yang ada diIndonesia dan berkembang baik baik pada daerah yang bersuhu antara $20-32^{\circ} \mathrm{C}$ dan kelembaban berkisar antara 65-80\%, pada tanah yang memiliki tekstur gembur/berpasir dan ada tumbuhan semak belukar. Jangkrik memiliki cara hidup bergerombol dan bersembunyi pada tumpukan-tumpukan dedaun yang kering atau pada bongkahan tanah. Gryllus vernalis aktif dimalam hari untuk mencari makan. Gryllus bimaculatus ini juga suka mengeluarkan suara dimalam hari. Gryllus ini termasuk herbivora pemakan tumbuhan dan hewan lainnya atau disebut omnivora dengan memakan bahan organik, termasuk bahan tanaman membusuk, dan jamur.Jumlah spesiesnya terdiri dari $26 \%$ dari seluruh spesies insekta. Fauna-fauna pemakan tumbuhan dapat bertahan hidup dengan memakan gulma dan bermanfaat untuk pengendalian gulma.Beberapa spesies telah digunakan dalam upaya pengendalian gulma secara hayati.

\section{Famili Blattidae}

Serangga dari famili ini yang ditemukan adalah Blattela spp. (kecoa). Adapun ciri-ciri dari serangga ini memiliki kisaran ukuran tubuh $27-35 \mathrm{~mm}$ atau lebih, tubuh warna cokelat kemerahan, dengan sayap berkembang dengan baik. Bentuk tubuh pipih, oval, bagian caput tersembunyi di bawah pronotum.Bagian sayap licin dan nampak keras, tidak memiliki rambut dan berduri. Imago dapat menggabungkan 30-40 telur dalam tempat yang kuat, tempat yang seperti kantung tersebut akan dibawa kemanapun sebelum menemukan tempat untuk bersembunyi. Pada ekosistem fauna ini memiliki peranan seperti sebagai pelebur seresah-seresah dan aktif pada waktu malam hari, dan pada waktu siang hari bersembunyi ditempat yang gelap.

\section{Famili Araneae}

Secara umum laba-laba mempunyai warna hitam, coklat tua, ataupun coklat muda kekuningan. Tubuh serangga ini terbagi 2 bagian cephalo thoraks (gabungan kepala dan dada) dan abdomen (perut). Jumlah kaki empat pasang.Yang betina mempunyai tubuh yang lebih besar dan bewarna lebih terang. Sedangkan yang jantan, ukuran tubuh lebih kecil dan bewarna gelap. Dari hasil pengamatan didapat bawa serangga tersebut memiliki ciri-ciri kaki bewarna lebih terang. 


\section{Famili Drosophilidae}

Famili Drosophilidae merupakan lalat buah. Spesies ini memiliki ciri-ciri yaitu warna tubuh kuning kemerahan, ukuran tubuh $3 \mathrm{~mm}$, mempunyai bulu - bulu dekat mulut, mata majemuk, besar. Antena pendek, torak 3 ruas, 3 pasang kaki, 4 ruas pada masing-masing kaki, tarsus 5 ruas, terdapat 1 pasang sayap membraneus, sayap belakang mereduksi (halter), abdomen terdiri dari 6 ruas, cembung, dengan warna abdomen bagian ventral berwarna putih sedangkan dorsal lorek-lorek (hitam-putih).

\section{Famili Oligosceata}

Famili ini memiliki panjang tubuh berkisar antara 55-105 $\mathrm{mm}$, lebar tubuh, 3,5-4 mm, jumlah segmen antara 190-209. Warnanya keputih-putihan dengan sedikit kecoklatan. Klitelium berwarna kekuning-kuningan, berbentuk sadel pada segmen ke 15-16, menebal pada bagian dorsal.

\section{KESIMPULAN}

Terdapat perbedaan tingkat keanekaragaman spesies insekta pada tanaman kakao menghasilkan dan tanaman belum menghasilkan. Pada tanaman menghasilkan terdapat 9 spesies sedangkan pada tanaman belum menghasilkan terdapat 7 spesies serangga. Indeks keanekaragaman (H') pada TM tergolong sedang, 1,68 sedangkan H' pada TBM 1,63 tergolong sedang. Tingkat keanekaragaman serangga pada tanaman TM dan TBM pada musim kemarau tidak berbeda dalam katagori sedang.

\section{DAFTAR PUSTAKA}

Borror, D. J., Triplehorn, C. A., \& Johnson, N. J. (1992). Pengenalan pelajaran serangga. Edisi keenam. Diterjemahkan oleh: Partosoedjono, S. dan Brotowidjoyo, M. D. Gadjah Mada University Press, Yogyakarta.

Gulan, P. J., \& Cranston. (2010). The insects: an outline of entomology. $4^{\text {th }}$ edition. Wiley-Blackwell

Haneda, N. F., Kusuma, C., \& Kusuma, F. D. (2013). Keanekaragaman serangga di ekosistem Mangrove. Jurnal Silvikultur Tropika, 4(1), 105-113.

Michael, P. (1995). Metode Ekologi untuk penyelidikan tanaman lapangan dan laboratorium. Terjemahan Yanti R. Koester. Universitas Indonesia Press, Jakarta.

Odum, E. P. (1998). Dasar-dasar ekologi. Edisi ketiga. Gadjah Mada University Press, Yogyakarta, $824 \mathrm{p}$.

Purba, G. L. (2014). Interaksi trofik jenis serangga diatas permukaan tanah dan permukaan tanah pada beberapa pertanaman varietas jagung (Zea mays Linn.). Skripsi. Universitas Sumatera Utara, Medan.

Rahmawaty. (2000). Keanekaragaman serangga pada tanah dan perannya pada komunitas Rhizopora spp. dan komunitas ceriops tagal di Taman Nasional Rawa Aopa Watumohai, Sulawesi Tenggara. Tesis. Institut Pertanian Bogor.

Sari, M. (2015). Identifikasi serangga dekomposer permukaan tanah hutan tropis dataran rendah (studi kasus di arboretum dan komplek kampus UNILAK dengan luas 9,2 ha). Bio-Lectura: Jurnal Pendidikan Biologi, 2(2), 140-149. https://doi.org/10.31849/bl.v2i2.324. 
Shannon, C. E., \& Weaver, W. (1949). The mathematical theory of communication. University of Illinois Press, Urbana, Illinois. 144 pp.

Siregar, R. A., Nasution, Z., \& Marheni. (2019). Exploration of macrofauna in Coffee plants. In IOP Conference Series: Earth and Environmental Science. 305. 012052.

Suin, M. I. (2012). Ekologi Hewan Tanah. Bumi Aksara, Bandung.

Szujecki, A. (1987). Ecology of forest insect. PWNPolish Scientific Publisher. Warszawa. 